\title{
Child Welfare: A critical analysis of some of the socio-legal legislations in India
}

\author{
Prof. Shilpa Khatri Babbar \\ Sociology Professor at Vivekananda Institute of Professional Studies, Delhi \\ (Affiliated to Guru Gobind Singh Indraprastha University, Delhi, India)
}

\begin{abstract}
Children are a human resource, invaluable but vulnerable. It is very essential to enable their development in such a manner that they bloom with joy in an atmosphere of a caring society. Various social legislations in India, focusing on an environment for a full booming of this essential human resource have undergone a sea change: from a position where children were treated as non-entity and mere material objects to a position of human dignity where conscientious efforts have been made to not only make them free from exploitation and abuses but also enable them to develop their full potentiality with fair access to food, health, education and respect. This paper makes a critical analysis of the existent legislations on child labour, issues related to adoption and sexual abuse of children.
\end{abstract}

Keywords: Adoption, Child Labour, Devadasis, Juvenile Justice, POCSO

\section{Introduction}

The Charter of Rights of Children (CRC) or the Geneva Declaration made by International Labour Organization (ILO) in 1924 was the first humanist effort to help their amelioration and to protect them against hazardous employment. Through a series of Recommendations and Conventions, the ILO had sensitized the public policy and influenced national policies especially against child labour. The UN Declaration of Rights of Children, 1959 highlighting the need for their "special safeguards and care" both, before as well as after birth, got concretised into UN Convention on Rights of the Child (CRC), 1989. This Convention recognised the significance of family, especially the importance of happiness, love and understanding as inherent requirements for complete and harmonious development of the child. In 1992, India became signatory to the Convention.

Four imperative sets of rights recognised for children in the Convention are the Rights to survival, protection, development and participation. Since India has ratified the Convention, the legal system and the society as a whole are required to respond seriously to the policy. This is in continuation of the constitutional commitment towards elimination of child labour and exploitations, protection of their health and promotion of their development through education and other assistance. Child labour, inter-country adoption, sexual exploitation of children and compulsory primary education are some of the most problematic areas in which law's efficacy is severely challenged.

\section{Child Labour}

The advent of industrialization and urbanization resulted in mass migration of rural population to urban centres. This further deepened the existent deprivation, and poverty. In the midst of homelessness and hunger, the children of migrant families were compelled to take upon themselves the arduous task to run the household by contributing financially.

Exposed to the chemicals, poisons and dangerous works; subjected to repetitive, monotonous and uncompromising drudgery; and to extensively stretched working hours without sufficient leisure and adequate pay, the children were imperilled of their physical health and mental growth [1]. Due to the above mentioned work related hazards along with denial of opportunity for natural development, exploitation arising from low wages and loss of valuable opportunity for schooling, child labour was recognized as a social evil. It is "economically unsound, psychologically disastrous and physically as well as morally dangerous and harmful" [2].

In 1924, ILO adopted a charter for children called Declaration of Geneva. The Convention 59 of the ILO prescribes that no child below the age of 14 shall be employed to work in any factory or mine or engaged in any other hazardous employment. India is a party to this Convention. Moreover, the Indian Constitutional policy on child protection is comprehensive as it is spread over children's entitlement arising from both prohibition of child labour and guarantee of right to education and state's duty to implement Directive Principles [3]. In fact the enhancement of state's duty to provide for free and compulsory education for all children until they complete the age of 14 to the position of correlative duty to a Fundamental Right under Article 21-A also has clear implication of eradicating child labour. 
The overall thrust of these provisions is prohibition of child labour in hazardous employment and regulation of child labour in non-hazardous employment. Apart from the various constitutional provisions, the Child Labour (Prohibition and Regulation) Act, 1986 was enacted in order to overcome the inadequacy of the Employment of Children Act, 1938 [4]. Section 3 of the Act has prohibited employment of children in certain occupations and processes. The paradox of coexistence of the policy of prohibition as well as regulation is justified in India's pervasive poverty which makes the complete elimination of child labour an almost impossible task.

In fact the prohibition under Section 3 is not absolute as it does not apply to any workshop wherein any process is carried on by the occupier with the aid of his family or to any school established by, or receiving assistance or recognition from government. By virtue of this proviso to Section 3, majority of child workers in India fall outside the ambit of the Act thereby lessening the effect of the law. Moreover, a majority of child labour occurs in the informal sector thereby hidden from the purview of any punitive measure.

In order to prohibit and eliminate worst forms of labour such as all forms of slavery or practices similar to slavery, such as sale and trafficking of children and the like, the ILO adopted Convention 182 in 1999, which prohibited the practice amidst children up to the age of 18. But a situational dilemma prevents the Government of India from ratifying this for the Convention provides for prohibition of employment of children below 18 years in hazardous occupations and processes, whereas in India, as per CLPRA, persons above 14years can work in hazardous occupations and processes.

The Act is also silent about the payment of wages to the child worker. Policy of payment wherein some states, notifying under the Minimum Wages Act, 1948, have required 60 percent of wages payable to adults encourages child labour. In this regard, the Karnataka High Court in A. Srirama Babu Case [5] highlighted the need to retard the trend. Some of the other landmark judgements in this regard are Rajangam v. State of T.N. [6] and M.C.Mehta v. State of T.N.[7]. It is in fact the judgment in the latter case where the court observed that at least 60 percent of the prescribed minimum wage for an adult employee in the factories doing the same job should be given to the children employed.

Another pronouncement of the Court having far-reaching importance is Bandhua Mukti Morcha v. Union of India [8]. The facts of the case highlight the extreme of exploitation wherein children were kidnapped and made to work in carpet weaving industry as slaves and were also subjected to physical torture. The Supreme Court emphasizing upon the need for education referred to the international commitment to provide compulsory primary education to fight such extreme forms of exploitation.

In 1987, the CLPRA gave rise to the National Child Labour Policy which contemplated upon imparting non-formal education to enable the children to acquire a level of equivalence with corresponding grade and level in formal system along with supplementary nutrition through mid-day meals, imparting of skills for income and employment generation, and effective enforcement of child labour law. The $86^{\text {th }}$ Constitution Amendment Act added $21 \mathrm{~A}$ affirming that every child between the age of 6 and 14 years has the right to free and compulsory education. The onus to ensure the Right to Education was put on the State. The amendment added a further clause in Article 51A which enjoins a parent or guardian to provide opportunities for education to his child or ward, as the case may be, between the age of 6 and 14 years but remained silent on the finances, 'quality of education' and quality of infrastructure to enable the imparting of education. In fact the inconsistency of Indian legislative measures regarding child labour and education $\left(86^{\text {th }}\right.$ Amendment arose from the $93^{\text {rd }}$ Amendment Act, 2001), reveal the lack of synchronization between the government education policy and policy on child labour.

In October 2006, the government expanded the list of prohibited hazardous occupations and included children working in the domestic sector as well as roadside eateries and motels. Later in September 2008, diving as well as process involving excessive heat (eg. working near a furnace) and cold; mechanical fishing; food processing; beverage industry; timber handling and loading; mechanical lumbering; warehousing; and processes involving exposure to free silica were added to the list of prohibited occupations and processes.

In December 2012, the Ministry of Labour and Development proposed to amend the Child Labour (Prohibition and Regulation) Act, 1986 and a Parliamentary Standing Committee on Labour (2013-14) was constituted. It was decided to rename the CLPRA, 1986 as the Child and Adolescent Labour (Prohibition) Act. It is proposed that the term 'adolescent' would include those who have completed their fourteenth year but not eighteenth while the term 'child' would include those who have not yet completed their fourteenth year or such age as may be specified the Right of Children to Free and Compulsory Education Act, 2009, whichever is more. Related amendments include increasing the age of prohibition for employment of children and adolescents in hazardous occupations such as mining and making offences under it cognizable and increasing the punishment. Through the CLPR Amendment Bill, 2012, it is also proposed to prohibit employment of children below the age of 14 years in all occupations and processes to facilitate their enrolment in schools in view of the Right of Children to Free and Compulsory Education Act, 2009. 
The Parliamentary Standing Committee on Labour also demanded a New Child Labour Policy to remove the fragmented approach on the issue. This recommendation was termed by the Ministry as a part of policy and implementation strategy and not part of bill under consideration. Further, the Ministry of Women and Child development under the Government of India (Allocation of Business) Rules, 1961 has been given the responsibility for enforcement of the Juvenile Justice (Care and Protection of Children) Act (JJA), 2000 (shall be discussed later), which includes a chapter on rehabilitation and social integration thereby avoiding duplication of provisions in the Amendment Bill. The matter of child trafficking is being handled by the AntiTrafficking Nodal Cell, set up under the Ministry of Home Affairs; Street and orphaned children were being taken care of under Ministry of Women and Child Development; and the National Child Labour Project Scheme provides for the rehabilitation of rescued children.

Currently, the Child Labour Law is in direct disharmony with the Fundamental Right to Education after ( $86^{\text {th }}$ Amendment to the Constitution, 2002) and the Right to Children to Free and Compulsory Education Act (RTE) passed in 2009. Since this right is applicable to all the children, it is quite ironical to place them at two different physical spaces i.e. school and work, at the same time. In fact even as raids and rescues of child labour revealed exploitation and abuse, CLPRA did not make child labour a cognisable offence, though this issue was somewhat addressed in Section 26 of JJA, 2000. However, the contradictions soon followed between JJA and CLPRA for the latter remains restricted to under 14 years old while JJA covers all the children under 18 years, in hazardous sections. The gravity of this issue is connected to the convenience of interest groups. Various policies and acts are also drafted keeping in mind the targeted employment criteria of that sector. While the social legislations define a child to be 18 years, most labour legislations define it as 14 . The National Census figures of the year 2001 reveal some very disturbing facts regarding the state of child labour in India. According to the report a whopping 12.6 million children between ages five and fourteen are child labourers. Despite the ratification of the United Nations Convention on the Rights of the Child (UNCRC) in 1992, and the articulation in Article 32 wherein the Government of India undertook to progressively ban all forms of child labour, the phenomenon still widely exists.

The only silver lining is the hope of the possible implementation of the proposed amendments through the pending CLPR Bill, 2012. The Ministry is also looking forward to ratify the ILO Conventions 138 and 182 , after the proposed amendments are accepted, because these amendments would put the Indian law in exact conformity with the Convention standards. These amendments in the existing law would also mean scaling up the state's efforts and responsibilities, enhanced expenditure and more involvement of the police and judiciary. In practical terms, the government is confronted with three major challenges: ascertaining enforceability, assessing the real magnitude of the problem and devising appropriate rehabilitative measures.

\section{Juvenile Justice (Care And Protection Of Children) ACT, 2000}

The Juvenile Justice (Care and Protection of Children) Act (JJA), 2000 is a legal framework for juvenile justice in India. It is essentially social welfare legislation, crafted specially to deal with offenders under the age of 18 and aimed at their proper care, protection and treatment through catering to their development needs. The Act provides a framework for the protection, treatment and rehabilitation of children in compliance of CRC, repealing the earlier Juvenile Justice Act of 1986 and has been further amended in 2006 and 2010.

Section 2(k) of the Act defines a "juvenile" or a "child" as a person who has not completed 18 year of age while 2(l) says a "juvenile in conflict with law" means a juvenile who is alleged to have committed an offence. Regarding determination of the age of a juvenile, the Act calls for a "due inquiry" by competent authority usually the Juvenile Justice Board. Rules under the Act lay down that medical opinion on the age of an accused be sought only if he fails to produce matriculation or an equivalent educational certificate, or a birth certificate in absence of the former.

Currently, in 2014, there is a proposal under consideration for a third amendment of the JJA as the present fails to express the minimum age, lacks concept of parental responsibility, and fails to provide for procedural guarantees like right to counsel and right to speedy trial. The Act does not take into account the orders and directions of the Supreme Court and High Courts relating to determination of the age of the child and empowers the Juvenile Justice Board to give a child in adoption. For successful compliance of Court orders, and to punish violators, monitoring bodies need to be set up, who should be given legal powers as well. One area where further action is required is that of providing a support person for children during the investigative process, courtroom appearance and after the trial is over, has much to commend itself, and would enable the child to have a single support person to help his/her navigate the entire process.

\section{Adoption And Related Issues}

Yet another issue pertinent to the policy of child welfare is adoption. A secular frame was given to adoption, under the Hindu Adoptions and Maintenance Act, 1956 (HAMA) which was equipped to solve the social problem of orphans, abandoned and refugee children. 
Under the HAMA only a Hindu can adopt a child and only a Hindu child can be adopted. After ratifying CRC and in response to its demands, the JJA, 2000, provides a machinery to ensure the welfare of children "in need of care and protection" or "in conflict with law".

Bridging the legal and cultural lags over the years, HAMA has undergone many changes, the most significant being the inclusion of non- Hindus in the act of adoption as parents rather than as mere guardians in the 2006 Amendment to the JJA, bypassing many of the religious personal laws that do not recognise adoption. In a landmark judgment, in February 2014, the Supreme Court gave Muslims the right to adopt a child with a view that the laws of land had to get primacy over personal law till the country achieves Uniform Civil Code. The judgment came on an 8 years old petition by Shabnam Hashmi who had approached the apex court after being refused permission to adopt. The court emphasised that the provisions relating to adoption under the JJA, can be availed by any person, notwithstanding the position of adoption under a personal law. This Act, unlike HAMA, is a general law that does not exclude any section of persons from its ambit.

Much in tune with the expected sentiments, the enactment of a general adoption law has been vehemently opposed by Muslims and Parsis. While the latters' religion prohibits the assimilation of an "outsider" into a Zoroastrian family, the former believe that their religious law totally prohibits adoption. This belief has not been dislodged in any of those Muslim countries that have reformed and codified Islamic family law - the only two exceptions are Turkey and Tunisia, where adoption has been permitted by law, subject to certain restrictions meant to accommodate clear provisions from the Quran.

In the Shabnam Hashmi case, the Supreme Court has so emphasised the enabling nature of the provision:

The act does not mandate any compulsive action by any prospective parent leaving such person with the liberty of accessing the provisions of the act, if he so desires. Such a person is always free to adopt or choose not to do so and, instead, follow what he comprehends to be the dictates of the personal law applicable to him.

But in this provision, the court has not addressed the fact that the Act requires the statutory Child Welfare Committees set up under its provisions to certify in every case that the child proposed to be adopted is "legally free to be adopted". If it is true that Islamic law prohibits adoption, then a Muslim child, as long as s/he is governed by Islamic law, will not be "legally free to be adopted".

Further, in the absence of any general law, foreigners wishing to adopt an Indian child have to take the circuitous route of securing guardianship of the proposed adoptee under the Guardians and Wards Act, 1890, taking her/him to their home country, and procuring adoption orders from courts there under the local law. India ratified the Hague Convention on Inter-Country Adoption (ICA) in June, 2003. For the implementation of its procedures, the Central Adoption Resource Authority (CARA), an autonomous body under the Ministry of Women and Child Welfare, was designated. The Ministry, pursuant to certain guidelines issued by the Supreme Court in a Public Interest Litigation (PIL) petition, Laxmi Kant Pandey v. Union of India [9], framed guidelines governing inter-country adoptions (which were first revised in 1994 and then in 2007).

In 1987[10], Justice Bhagwati clarified that in case of a foreigner living in India for one year or more, the Home Study Report and other connected documents prepared by the recognized placement agency should be regarded as sufficient. However, the apex court, in Smt. Anokha vs. State of Rajasthan [11] has held that the guidelines, laid by Justice Bhagwati, would not be applicable where the child is living with his or her biological parents, who have agreed to give their child in adoption to a known couple, who may be of foreign origin. In such cases, the court has to deal with the application under the Guardian and Wards Act, 1890.

While critically looking at child welfare, a fear which continuously surrounds adoption is trafficking of children for and through adoption. Keeping this in mind, the Madras High Court, on inter-country adoption, in Mr. Tim Cecil vs. Unknown(2011), vehemently put across that the children are not properties of their parents so as to entitle the latter to have an absolute dominance over the former. In a country where abject poverty drives a few families to sell their children for beggary, forced labour or prostitution, it was not considered safe to rely entirely upon the wisdom of the biological parents to give their children in adoption or foster care to foreigners. Further, the petitioners neither possessed a Home Study Report regarding their economic, social, familial and physical status nor were they sponsored by a recognised adoption agency as required under ICA laws. The court also argued that the judgment in the Anokha case was incompatible with the Hague Adoption Convention on Protection of Children and Cooperation in Respect of Inter-country Adoption, ratified by the Government of India for it does not recognise any case of direct adoption and the receiving country will not issue permission under Article 5/17 of the Convention to agree to such kind of adoption without the involvement of recognised agencies and authorities. Adoption, it was argued, has evolved as a method of providing alternative care for children deprived of a healthy and happy environment and was seen as a mode of enforcement of the fundamental rights of the child and not as an exercise of the rights of the biological parents over the child. 
In absence of an effective legislation for such adoptions, the above discussion makes it apparent that they are handled with strict supervision through series of precedents. ICA was restricted to 80:20 ratio so as to curb child trafficking under the garb of adoption.

In 2014, to make things easier in this context, the Supreme Court issued a set of guidelines for ICA, with a direction that it be followed strictly until Parliament enacts a proper law on the subject. Simplifying the adoption process for, non-resident Indians, overseas citizens of India, and persons of Indian origin, it is proposed to treat hereafter the couples of Indian origin who live abroad on a par with Indians living in India if they want to adopt a child from the country. The idea behind this is to shorten the growing list of children waiting to be adopted at India's orphanages and that of couples waiting to adopt them.

There is a need to look at adoption and adoption laws in a way that the society can provide a healthy and happy upbringing to less- privileged children. The attempt at identifying one perfect model for this purpose may be both fruitful and fruitless, for a holistic approach towards child care involves treading a fine line between exclusion and inclusion, and between the diverse interests and conflicts that make up society. It is difficult to say whether care comes first, or the requisite provisions for such care.

\section{Sexual Abuse Of Children}

Sexual abuse of children, in view of vulnerability of their condition, and detrimental impact of the exploitation on their health and life, is a problem of great concern. In its 2013 report [12], titled, 'India's Hell Holes: Child Sexual Assault in Juvenile Justice Homes', the Asian Centre for Human Rights said that sexual offences against children in India have reached epidemic proportion. According to a 2007 study by the Indian Government of nearly 12,500 children from across India, 53perecnt of children - boys and girls equally - were victims of sexual abuse. Bitter Chocolate [13] revealed that child sexual abuse is not just atypical of lower income groups. Amongst the middle and upper-class families, one in every four boys and one in every three girls, below the age of 18 , have suffered from sexual abuse. What is a major source of concern is the fact that 50percent of the abusers are adults in position of their trust, including at home. In this background, Protection of Children from Sexual Offences (POOCSO) Act was envisaged in 2012.

One of the most evil forms of child sexual abuse is child prostitution, dealt with under Immoral Traffic (Prevention) Act (IITPA), 1956. In India nearly 1.2 million sex workers are below the age of 18 with about 40 underage girls being forced into prostitution on a daily basis. With the 8 percent of increase in the flesh trade, India has become one of the prominent names in child prostitution. For resolving the problem of rehabilitation of the children of prostitutes and minor prostitutes, the Supreme Court in Gaurav Jain v. Union of India [14] activated the provisions of JJA, 1996. Referring to the international instruments on rights of children, the Court gathered positive policies for their rehabilitation, education and development. Article 19 of the CRC, enjoins the states to protect the child from all forms of maltreatment or exploitation including sexual abuse. It referred to Principle 9 of Declaration of Rights of Children, which provides that the child shall be protected against all forms of neglect, cruelty and exploitation and shall not be the subject of traffic in any form. Article 21 of the Constitution, in its changed perception and read with Directive Principles of State Policy, admits right to life with human dignity. In the light of these values the JJA was interpreted to compel for giving a meaningful life to child prostitutes and children of prostitutes, who come under the category of neglected juvenile.

Paradoxically, under the sanctity of religion, the profanity of child prostitution is hidden in the practise of Devadasis prevalent in some parts of Maharashtra, parts of southern India, including Andhra Pradesh, whereby parents marry a daughter to a deity or a temple. The marriage usually occurs before the girl reaches puberty and requires her to become a prostitute for upper-caste community members. Such girls are known as jogini and are forbidden to enter into a real marriage. They are required to serve the temple with song, music or dance but most of them are effectively temple prostitutes. Higher caste men come and have sex with them for as little as 20 rupees [15].

This 'dedication' was outlawed in Karnataka in 1982 and in all of India in 1988[16], but still flourishes under the carpet. With their mothers having children from multiple fathers, the girls are abandoned and without intervention compelled to follow the same pattern of life of their mothers. Sometimes higher castes ensure that a girl goes into devadasi service instead of the family paying debts that are owed. It is effectively a form of child trafficking and child bonded labour which under the domain of culture, is deeply rooted in these societies. Poverty and 'untouchablity' contribute to the persistence of this practice.

To bridge up the existent gap between law and society there is a need for a continuous interaction similar to the sociological approach to law initiated in Gaurav Jain case wherein NGOs were involved for effectuating the legal spirit.

Though streaks of sensitivity in cases of child sexual abuse can be viewed in the State of Maharastra v. Dr. Praful Desai [17] and Sakshi v. Union of India [18] but till 2012, there was no specific law to address this. In 2012, expanding the definition of child sexual abuse, POCSO Act, was envisaged. Under the act, a 'child' is defined as any person below the age of 18 years and is provided protection from sexual abuse. It also intends to 
protect the child through all stages of judicial process and gives supreme importance to the principle of "best interest of the child". POCSO covers penetrative and aggravated penetrative sexual assault, sexual and aggravated sexual assault, sexual harassment, and using a child for pornographic purposes. It envisages punishing even abetment or an attempt to commit the offences defined in the act and recognizes that the intent to commit an offence, even when unsuccessful needs to be penalized.

Expanding the ambit of responsibility, it suggests that any person, who has an apprehension that an offence is likely to be committed or has knowledge that an offence has been committed, has a mandatory obligation to report the matter. Further, it is now mandatory for police to register an FIR in all cases of child abuse. A child's statement can be recorded even at the child's residence or a place of his choice. Child Welfare Committees (CWC) play a vital role under the POCSO Act for they are required to take into account the opinion of the child to decide on the case within three days and conclude whether the child should remain in an institution or be with the family. CWC are also required to nominate with the consent of the child parent / guardian / other person who the child trusts, a support person to assist the child during the investigation and trial of the case.

The State Commissions for Protection of Child Rights (SCPCR) has been empowered with the responsibility of monitoring the implementation of the provisions of POCSO Act, to conduct inquiries and to report the activities undertaken under the 2012 Act, in its annual report. Further, keeping in view the vulnerability and innocence of children, for offences under this act the burden of proof is shifted on the accused. To prevent misuse of the law, punishment has been provided for false complaints or false information with malicious intent. Media has been barred from disclosing the identity of the child without the permission of the special court.

Despite its transformative power, POCSO - a necessity in India where $41.1 \%$ of the population is below the age of 18[19] and where over 7, 200 children, including infants are raped every year [20] — is not complied with despite being in the statute book. In the infamous Apna Ghar Rohtak shelter home case of May 2012, where over 100 inmates were allegedly subjected to sexual abuse, the POCSO provisions have reportedly still not been invoked against the accused. The most shocking part of this case is the director of the shelter home was then recently titled as the "woman role model of the year". Despite the fact, that under the JJA, 2000, all existing children's residential care facilities are supposed to register with the government within 6 months, with CWCs mandated to inspect them, there are no legal provisions for penalties on those who do not comply. Insofar as child sexual abuse is concerned, though POCSO is a wholesome law but there is a strong urgency to ensure its implementation and create awareness amongst officers and all stakeholders on what it contains. The act defines exclusively the crime of sexual offences against children and fulfils the mandatory obligations of India as a signatory to the United Nations Convention on the Rights of the Child, acceded to on December 11, 1992. But these systems often do not work due to poor policing and the failure of social services to function properly.

\section{Conclusion}

Despite the new and in fact perceptible sensitive laws to ensure child welfare, there are apparent gaps in accomplishing the envisioned objective. This is because of the inconsistencies which exist between the various existent laws. In order to achieve the objective, there is an urgent need to view them all holistically and thereafter to iron out the existent contradictions. This would make implementation of the existent laws more rigorous and effective. Further, the endless quantitative categorization of the term "child" itself leads to great amount of ambiguity and also encourages non-compliance. Successful implementation of any law demands a coherent understanding and structural application, which is absent in case of laws ascertaining the identity and social dignity of children in India.

\section{References}

[1]. Gurupadaswamy Committee, Report of the Committee on Child Labour, Ministry of Labour, Government of India, New Delhi 1979, page 8

[2]. Gurupadaswamy Committee, Report of the Committee on Child Labour, Ministry of Labour, Government of India, New Delhi 1979, page 10

[3]. Article 24, 39(e), 39(f), 41, 47

[4]. Realized in People's Union for Democratic Rights v. Union of India (1982) 3 SCC 235:1982 SCC (L\&S) 275

[5]. A. Srirama Babu v. Chief Secy., Govt. of Karnataka, ILR (1997) Kar 2269

[6]. (1992) 1 SCC 221: 1992 SCC (L\&S) 105 Employment of children in beedi manufacture was considered as violating the Beedi and Cigar Workers (Conditions of Employment) Act, 1996 and the CLPRA, 1986 by the Supreme Court.

[7]. (1996) 6 SCC 756: 1997 SCC (L\&S) 49: AIR 1997 SC 699 The Supreme Court noted that in Sivakasi children were employed in the manufacturing process of matches and fireworks and regarded it as hazardous.

[8]. (1997) 10 SCC 549

[9]. (1984) 2 SC 244; AIR 1984 SC 469

[10]. (2004) 1 SCC 382

[11]. AIR 1987 SC 232 at p. 240, para 12 
[12]. Gurjot Singh, India's Hell Holes - Child Sexual Assault in Juvenile Justice Homes (Report released by Delhi's Asian Centre for Human Rights (ACHR), 2013)

[13]. Pinki Virani, Bitter Chocolate: Child Sexual Abuse in India, 25 ${ }^{\text {th }}$ Edition (Penguin Books India, 2013)

[14]. Gaurav Jain v. Union of India, (1997) 8 SCC 114: AIR 1997 SC 3021

[15]. Catherine Rubin Kermorgant, Servants of the Goddess: The Modern-Day Devadasis (Random House India, 2014)

[16]. It was in 2006 that the state passed the Maharashtra Devdasi Tradition (Abolition) Act, 2005

[17]. (2003) 4 SCC 601

[18]. (2004) AIR 2004 SC 3566

[19]. Census of India, 2011

[20]. Report by Human Rights Watch, Breaking the Silence: Child Sexual Abuse in India, (United States of America, 2013) 